\title{
A CONSTITUCIONALIZAÇÃO DO DIREITO ADMINISTRATIVO E SEUS REFLEXOS SOBRE A DISCRICIONARIEDADE ADMINISTRATIVA
}

\author{
Amanda Fontelles Alves* \\ Daniel Silva Fampa*
}

\section{RESUMO}

A Constitucionalização Direito Administrativo, bem como a evolução apresentada pelo princípio da legalidade, irradiou efeitos sobre a atuação da Administração Pública. Este fenômeno ampliou o rol de princípios e normas no texto constitucional, enquanto fez crescer no Direito Administrativo o número de temáticas infraconstitucionais sobre a Administração na Constituição Federal. O reflexo imediato destes eventos foi restringir o limite de atuação do administrador público que, na contemporaneidade, onde vigora o Estado Democrático de Direito, encontra-se vinculado tanto aos ditames legais quanto aos objetivos abalizados na Lei Maior. E isto, por sua vez, impactou no exercício do seu poder discricionário.

Palavras-chave: Constitucionalização. Direito Administrativo. Princípio da Legalidade. Atuação do Agente Público. Discricionariedade Administrativa.

\section{THE CONSTITUTIONALISING OF ADMINISTRATIVE LAW AND ITS EFFECTS ON THE PUBLIC ADMINISTRATOR DISCRETIONARY POWER}

\begin{abstract}
The Constitutionalising of Administrative Law, as well as the evolution on the principle of legality, radiated effects on the Public Administration. It amplifies the principles and rules on the constitutional body, while applied to Administrative Law made grow the number of infraconstitutional themes about the Administration on the Constitution. The reflection of these events was to restrict the limits of action of the public administrator, and in the Democratic State of Law, it is possible to find it bound to both legal dictates and authoritative goals in the Major Law. This reverberated on the exercise of its discretionary power.
\end{abstract}

Keywords: Constitutionalising. Administrative Law. Principle of Legality. Action of the Public Administrator. Discretionary Power.

\section{NOTAS INTRODUTÓRIAS}

Em regra, entende-se o Direito como uma locução prescritiva criada com a finalidade de disciplinar os comportamentos humanos, tornando possível a vida em sociedade. Por sua vez, "o direito administrativo é o ramo do direito público que disciplina o exercício da função administrativa, bem como as pessoas e órgãos que a desempenham” (MELLO, 2014, p. 29). Em outros termos, o Direito Administrativo é o ramo do Direito Público que concentra esforços no estudo dos princípios e normas reguladoras do exercício da função administrativa. 
Cumpre, portanto, mesmo que brevemente, buscar identificá-la. A função pública, no Estado Democrático de Direito, é a atividade exercida no cumprimento do dever de concretizar o interesse público, mediante a utilização dos poderes instrumentalmente necessários e que tenham sido previamente conferidos ao agente público pela ordem jurídica.

Assim, apresenta-se como verdadeira a assertiva de que o Direito Administrativo se desenvolveu com base em duas ideias antagônicas, quais sejam: (i) a da proteção aos direitos individuais perante o Estado, com fundamento no princípio da legalidade; e (ii) a da necessidade de satisfação dos interesses públicos primários, o que determina a concessão de prerrogativas e privilégios à Administração Pública. Ocorre que estes benefícios de atuação concedidos legalmente ao administrador não servem apenas para limitar o exercício de determinados direitos individuais, mas também para consagrar o bem-estar da coletividade.

Em que pese à existência desta dicotomia, a Administração deve trabalhar com o conceito de equilíbrio, ou seja, precisa harmonizar ambas as ideias que, em muitas situações, apresentam-se como interesses diametralmente opostos. Isto é possível porque, normalmente, os limites tanto aos direitos do indivíduo quanto ao exercício da autoridade e das prerrogativas estatais estão previstos no próprio ordenamento jurídico. Não é algo que a autoridade administrativa faça arbitrariamente, pois tem o dever de respeitar os limites estabelecidos pela lei e, mais recentemente, também aqueles previstos no texto constitucional.

A passagem do Estado Liberal para o Estado de Direito possibilitou a intensificação de dois fenômenos distintos, o da constitucionalização do Direito Administrativo e o da evolução do princípio da legalidade. A partir disto, o Poder Público passou a atender não apenas os ditames estabelecidos em lei, mas os princípios e normas previstos na Constituição de 1988, mesmo quando o legislador infraconstitucional não menciona nada a respeito.

Dito isto, o objetivo deste artigo é demonstrar a ocorrência destes dois eventos, bem como analisar os seus reflexos sobre a atuação da Administração Pública, especialmente em relação ao seu poder discricionário. Importa questionar: houve uma redução da discrição?

\section{A CONSTITUCIONALIZAÇÃO DO DIREITO}

O fenômeno da constitucionalização do Direito teve sua origem com a aproximação entre constitucionalismo e democracia nacional. Nos Estados de democratização mais tardia, como o Brasil, observa-se que a constitucionalização é um processo recente, mas intenso. 
A expressão "constitucionalização do Direito" é recente na terminologia jurídica e abarca vários sentidos. Poderia, a princípio, fazer referência a um (i) ordenamento jurídico no qual vigorasse uma Constituição dotada de supremacia, mas também poderia igualmente (ii) identificar o fato de o texto constitucional incorporar inúmeros temas afetos aos ramos infraconstitucionais do Direito. A despeito de serem estes fenômenos que contribuem para a problemática ora abordada, o presente trabalho demanda foco em um terceiro sentido.

A ideia de constitucionalização a ser explorada está associada à (iii) expansão significativa das normas constitucionais, cujo conteúdo material e axiológico se propaga, com força normativa, para todo o sistema jurídico. Com isto não se pretende afirmar que os conteúdos de outros ramos do Direito, como o Administrativo e o Tributário, não influenciam na interpretação jurídica, mas apenas demonstrar que os valores, os fins públicos e os comportamentos presentes nos princípios e nas regras da Constituição Federal passam a condicionar a validade e o sentido das normas infraconstitucionais (BARROSO, 2012, p. 32).

Desde o fim do regime militar, e com a promulgação da Constituição Federal de 1988, o texto constitucional passou a ocupar o centro do sistema jurídico e a desfrutar não apenas da supremacia formal, mas da supremacia material ou axiológica, engrandecida pela abertura do sistema jurídico e pela normatividade de seus princípios. Em outros termos, a Carta Magna passou a funcionar como parâmetro de validade para a ordem infraconstitucional e como vetor principal de interpretação de todas as normas que compõem o sistema jurídico brasileiro.

Como consequência, a constitucionalização, além de repercutir nas relações privadas ao impor limites implícitos e explícitos à autonomia da vontade das partes, tem influenciado a atuação dos três Poderes, notadamente em sua relação com os particulares. Relativamente ao Poder Legislativo, a constitucionalização impõe deveres de atuação para a realização de direitos e/ou programas constitucionais. Já em relação ao Poder Judiciário, aquela serve de parâmetro para o controle de constitucionalidade e condicionante na interpretação das normas.

No tocante à Administração Pública, a moderna constitucionalização do Direito tem limitado a discricionariedade, imposto deveres de atuação e fornecido fundamento de validade para a prática de atos de aplicação direta e imediata da Constituição, independentemente da vontade do legislador infraconstitucional. Eis o ponto central, que será abordado mais adiante. 1.1 A Constitucionalização do Direito Administrativo 
No contexto histórico ocidental, importa esclarecer que a presença de dispositivos sobre a Administração Pública nas Constituições modernas teve início com as Cartas italiana e alemã, cujos precedentes foram ampliados pelas Cartas portuguesa e espanhola.

A introdução de matérias infraconstitucionais no texto constitucional sempre foi um registro presente no ordenamento jurídico brasileiro. Todas as Constituições nacionais apresentaram matérias de Direito Administrativo. Todavia, a inserção mais significativa ocorreu na Constituição de 1934, sendo mantida pelos textos constitucionais subsequentes.

Com a promulgação da Constituição vigente, no final da década de 1980, e com as emendas constitucionais posteriores, a constitucionalização tomou forma, se firmou como fenômeno moderno e atingiu seu ápice com uma explosão já aguardada. Hoje, observar-se algo que nunca antes havia sido anotado: é certo que a Constituição de 1988 possui um capítulo exclusivo sobre a Administração Pública e prevê diversas normas acerca do servidor público, do dever de licitar, da função social da propriedade rural e urbana, dentre outros.

Neste sentido, a constitucionalização do Direito Administrativo no Brasil expressa: (i) a existência de normas constitucionais direcionadas para a disciplina da Administração Pública; (ii) as transformações sequenciais sofridas pelo Poder Público brasileiro nos últimos anos e; (iii) a influência dos princípios constitucionais sobre as categorias deste ramo jurídico.

Como virtudes a serem destacadas, pode-se elucidar a dissociação entre a função administrativa e a atividade de governo, além da enunciação expressa de princípios setoriais próprios do Direito Administrativo no caput do artigo 37 da Constituição Federal. Em sua redação original estavam previstos os princípios da legalidade, impessoalidade, moralidade e publicidade. Porém, a Emenda Constitucional nº 19, de 04 de junho de 1998, acrescentou àquele dispositivo um quinto mandamento nuclear do sistema, o princípio da eficiência.

Desta maneira, para além dos outros fatores que impulsionaram a constitucionalização do Direito Administrativo, como a extinção de determinadas restrições de capital estrangeiro, a flexibilização dos monopólios estatais e a desestatização de setores da economia, o que merece maior destaque é a incidência no seu domínio dos princípios constitucionais expressos e implícitos. A centralidade no princípio da dignidade da pessoa humana e o foco na preservação dos direitos fundamentais alterou significativamente a relação entre a Administração e seus administrados, ocasionando a reformulação de paradigmas tradicionais.

Dentre estes paradigmas, o ilustre doutrinador Luís Roberto Barroso (2012, p. 49-50) enuncia três: (i) a redefinição da ideia de supremacia do interesse público sobre o interesse 
privado; (ii) a vinculação do administrador público à Constituição e não apenas à legislação ordinária e; (iii) a possibilidade de controle jurisdicional do mérito administrativo.

Em relação à chamada desmistificação da supremacia do interesse público ${ }^{1}$, importa realizar a distinção entre o interesse público primário e secundário. Para a maior parte da doutrina tradicional, o interesse público primário representa o conjunto dos interesses públicos individuais, ou seja, o verdadeiro interesse da coletividade, que pode ser sintetizado em valores como justiça e bem-estar social, enquanto que o interesse público secundário seria o conjunto de interesses da Fazenda Pública, como pessoa jurídica de direito público interno ${ }^{2}$. Com base nesta distinção, o interesse público secundário da Administração não deve, em abstrato, gozar de supremacia em face do interesse particular. Se ambos entrarem em conflito, ao intérprete caberá realizar a ponderação dos interesses presentes no caso concreto.

A ideia de vinculação do administrador ao ordenamento constitucional coloca "um ponto final" na noção de que a Administração estaria vinculada somente pela legislação, a partir da leitura tradicional do princípio da legalidade, pela qual sua atuação deveria ser guiada por aquilo que o legislador determinasse e/ou autorizasse. A constitucionalização do Direito introduz um novo fundamento ao agir administrativo. Nos dias atuais, o administrador pode, ou melhor, deve atuar com base nos ditames constitucionais e, independentemente (como acontece em muitos casos), de uma manifestação do legislador infraconstitucional.

Diante deste novo cenário pode-se inferir que "o princípio da legalidade transmuda-se, assim, em princípio da constitucionalidade ou, talvez mais propriamente, em princípio da juridicidade, compreendendo sua subordinação à Constituição e à lei, nessa ordem" (BARROSO, 2012, p. 50). Este entendimento repercute diretamente no terceiro paradigma.

A vinculação do administrador aos ditames constitucionais ampliou o controle judicial dos atos administrativos. É válido informar que, segundo a doutrina tradicional, o magistrado só poderia analisar os aspectos da legalidade do ato administrativo (competência, forma e finalidade) e não o seu mérito (motivo e objeto), nele incluídas a conveniência e oportunidade de sua prática. Mas isto tem mudado, uma vez que os princípios constitucionais gerais, bem como os específicos, especialmente o da razoabilidade e da proporcionalidade, tem permitido

\footnotetext{
${ }^{1}$ Para aprofundar nesta discussão, recomenda-se a leitura da seguinte obra: PIETRO, Maria Sylvia Zanella di.; RIBEIRO, Carlos Vinícius Alves Ribeiro (Coord). Supremacia do Interesse Público: e outros temas relevantes do direito administrativo. Rio de Janeiro: Atlas, 2010.

${ }^{2}$ Para maiores informações sobre o tema, vide MELLO, Celso Antônio Bandeira de Mello. Curso de Direito Administrativo. São Paulo: Editora Malheiros, 2014 e MOREIRA NETO, Diogo de Figueiredo. Curso de Direito Administrativo. 16 ${ }^{\mathrm{a}}$ ed. Rio de Janeiro: Editora Forense, 2014.
} 
o controle da discricionariedade administrativa, desde que com contenção e prudência para que o mérito da Administração Pública não seja substituído pelo chamado mérito judicial.

\subsection{A Evolução do Princípio da Legalidade}

Conforme explicitado, com a constitucionalização do Direito alguns princípios ganharam força, tendo em vista que passaram a assumir o status constitucional. Assim, o principal aspecto do fenômeno ora tratado é a aplicação obrigatória por parte do agente administrativo dos princípios constitucionais mesmo sem a anuência expressa do legislador.

Registra-se, por conseguinte, o que a doutrina intitulou de subordinação da lei ao Direito, tendo em vista que todos os valores e princípios presentes na Constituição devem ser respeitados e consagrados pelos Poderes Judiciário, Legislativo e Executivo. Neste contexto, urge destacar que o princípio da legalidade ${ }^{3}$ ganhou amplitude, merecendo atenção especial.

Renomados autores têm discorrido sobre uma suposta "crise" do princípio da legalidade, provocada por dezenas de fatores, dentre eles a constitucionalização do Direito Administrativo. Neste ponto, concorda-se com a professora Maria Sylvia Zanella Di Pietro, pois "não tem sentido falar em crise se, com isso, o intuito é isentar a Administração Pública do cumprimento da lei, porque isto significaria acabar com o Estado de Direito" (2012, p. 83). O fato é que, como tantos institutos do Direito, e deste acontecimento não seria excluído o Direito administrativo, o princípio da legalidade tem suportado uma constante evolução.

No Direito brasileiro, comumente se conceitua o princípio da legalidade como o princípio basilar do regime jurídico-administrativo, já que o Direito Administrativo nasce com o Estado de Direito e se apresenta, por conseguinte, como consequência dele. Em outros termos, representa a submissão do Estado à lei ao demonstrar que a atividade administrativa é infralegal. Destarte, a função do ato administrativo só pode ser a de realizador do enunciado legal, nunca podendo instaurar originariamente qualquer restrição aos direitos de terceiros.

Nos dizeres de Afonso Rodrigues Queiró, a Administração "é a longa manus do legislador" e "a atividade administrativa é atividade de subsunção dos fatos da vida real às categorias legais" (1968, p. 09). Corroborando com este pensamento, o jurista Celso Antônio Bandeira de Mello ensina que "o princípio da legalidade, no Brasil, significa que a Administração nada pode fazer senão o que a lei determina" (2014, p. 108).

\footnotetext{
${ }^{3}$ Vide art. $5^{\circ}$, inciso II; art. 37, caput e art. 84, inciso IV da Constituição Federal de 1988.
} 
Acontece que esta conceituação da legalidade não corresponde ao seu sentido original. Logo, prescinde esclarecer que a evolução sofrida pelo princípio da legalidade percorreu variadas fases, todas em sintonia com as transformações do modelo de Estado de Direito.

Na segunda fase do Estado Moderno, momento de instauração do Estado de Direito, abandonou-se o Estado de Polícia, em que a Administração Pública não se sujeitava à lei e nem podia ser objeto de controle por parte do Poder Judiciário. Já no primeiro momento do Estado de Direito, com o liberalismo, formularam-se novos princípios com o objetivo de proteger o cidadão do Poder Público como, por exemplo, o da isonomia, da separação dos Poderes e o da legalidade. A preocupação era com a proteção da liberdade individual dos cidadãos, reconhecidos como detentores de direitos fundamentais, universais e inalienáveis, conforme proclamado pela Declaração de Direitos do Homem e do Cidadão, de 1978.

O surgimento do Estado Liberal, em que pese ter consagrado o princípio da legalidade, ainda concedia ampla margem de atuação ao Poder Estatal, uma vez que a acepção de legalidade era muito mais restrita do que a implementada atualmente. Entendia-se o princípio da legalidade como "vinculação negativa" que, na prática, significava que a Administração podia fazer tudo aquilo que a lei não proibia. O papel da legislação nacional se restringia a definir as esferas jurídicas dos cidadãos como limite ao arbítrio do poder. Assim, com uma maior liberdade de atuação, o Poder Público usufruía de uma ampla discricionariedade.

Após os eventos dramáticos e os abusos cometidos contra os direitos humanos durante a Segunda Guerra Mundial (1939-1941), os movimentos que clamavam por mudanças se intensificaram. A preocupação com a liberdade cedeu espaço para a consagração da isonomia. Não tardou e a vertente democrática passou a impulsionar a atuação do Estado com o escopo de possibilitar a intervenção estatal em todas as áreas do domínio econômico e social para assegurar a igualdade entre cidadãos e garantir a manutenção da paz na sociedade moderna.

Por conta da influência do positivismo jurídico toda atividade administrativa passou a submeter-se à legislação, resultando na substituição do princípio da "vinculação negativa" pelo da "vinculação positiva", segundo o qual a Administração somente poderia fazer o que a lei permitia. Como consequência da expansão do conceito de legalidade, a discricionariedade começou a ser entendida como poder jurídico, na medida em que implicava certa margem de liberdade de atuação, desde que respeitados os limites legais, pois se entendeu necessário atribuir ao Executivo poder normativo, visto que o Legislativo não teria condições de legislar 
sobre todas as novas atribuições administrativas do Estado, seja por sua complexidade ou pela enorme quantidade de normas necessárias para disciplinar a atuação da Administração.

$\mathrm{Na}$ terceira fase do Estado de Direito, instaurada com a proclamação do Estado Democrático e a vivenciada na atualidade, foram introduzidas duas ideias fundamentais: (i) a de participação do cidadão na gestão e no controle da Administração e; (ii) a da legalidade vista sob o aspecto material ou axiológica, e não unicamente formal. Portanto, o momento histórico vivenciado se preocupou em inaugurar uma nova vertente do princípio da legalidade, com base no fortalecimento do processo de constitucionalização do Direito Administrativo.

\section{A DISCRICIONARIEDADE ADMINISTRATIVA}

De acordo com Seabra Fagundes "administrar é aplicar a lei de ofício" (1975, p. 17). Igualmente, Cirne Lima ensina que "jaz, consequentemente, a Administração Pública debaixo da legislação que deve enunciar a regra de Direito" (2007, p. 40). Nota-se, em uma primeira leitura, que a função do Poder Executivo e a posição dos atos administrativos viabilizadores de seu comportamento seriam delimitados única e exclusivamente pelos ditames legais.

Pois bem. Toda e qualquer lei estabelece um quadro dotado de objetividade dentro do qual podem se movimentar os sujeitos de direito, sendo o grau desta objetividade variante. Em todas as situações jurídicas pode-se observar uma limitação que delineia a conduta do sujeito responsável por aplicar o Direito ao caso concreto. Tal liberdade, contudo, pode ser mais ou menos ampla, a depender dos dizeres presentes nos dispositivos sobre a matéria.

Preconiza Celso Antônio Bandeira de Mello (2014, p. 979):

Qualquer regulação normativa é, por definição, o lineamento de uma esfera legítima de expressão e ao mesmo tempo uma fronteira que não pode ser ultrapassada, pena de violação do Direito. Este extremo demarcatório tem necessariamente uma significação objetiva mínima precisamente por ser e para ser, simultaneamente, a linha delimitadora de um comportamento permitido e a paliçada que interdita os comportamentos proibidos.

É no interior desta moldura legal que surge a chamada discricionariedade. Fala-se em poder discricionário quando a lei faz remanescer em proveito do aplicador do Direito certa margem de liberdade, que deverá ser preenchida com seu juízo subjetivo, a fim de satisfazer a finalidade legal no caso concreto. Assim sendo, na discricionariedade o legislador atribui ao executor do Direito a competência para selecionar, diante das peculiaridades da situação, a opção mais apropriada (dentre as demais possíveis) para fazer vigorar os preceitos legais. 
No geral, a discricionariedade é expressão que designa poder de escolha. Analisando a origem da palavra, nota-se que a mesma provém do termo discricionário ${ }^{4}$, o que é deixado à escolha de alguém, isto é, que é ilimitado ou livre de condições (MARRARA, 2012, p. 211).

Porém, não há de se pensar que a discricionariedade resulta da ausência de lei. Ao contrário, ela procede da própria disciplina normativa. É o ordenamento jurídico, através de seus dispositivos legais, que concede ao aplicado do Direito uma margem livre de atuação. Este é o motivo pelo qual a discricionariedade não se confunde com arbitrariedade. Quando o administrador público atua de forma discricionária, ele o faz em decorrência da vontade expressa do legislador e em conformidade com o sistema jurídico, e não de maneira arbitrária.

No Direito Público, discricionariedade denota poder de escolha do Estado que deve ser exercido pelos agentes públicos e, subsidiariamente, pelos entes privados responsáveis por executar funções públicas. Mas vale lembrar que este não é um conceito exclusivo do Direito Administrativo, vez que o poder de escolha também vale para autoridade legislativa e judicial.

Acontece que, ainda que exista em outros ramos jurídicos do Direito Público, o poder estatal de escolha é de importância ímpar para o exercício da função administrativa. Neste campo, impõe-se garantir ao administrador certa margem de criatividade para elaborar, bem como desenvolver e aplicar as medidas razoáveis e eficientes na solução de um problema ou na formulação de um programa ou plano necessário para a concretização de políticas públicas.

E o que justificaria a existência da discricionariedade? As duas razões apresentadas pela doutrina são simples. Em primeiro lugar, o Poder Legislativo não está em condições de prever todos os fenômenos que estão sujeitos à ação, intervenção e/ou controle estatal. E, mesmo que tivesse, dificilmente conseguiria definir previamente as medidas administrativas mais adequadas para cada caso concreto, tendo em vista que as possibilidades são infinitas.

Como é sabido, o Direito sempre pretende alcançar a medida capaz de atender ao interesse público. A variedade de situações fáticas passíveis de ocorrerem, as quais serão necessariamente distintas entre si pelas circunstâncias que as envolvem, revela a necessidade de conceder ao agente público o poder de proceder à eleição da medida idônea para atingir de modo satisfatório o objetivo da legislação aplicada. O legislador, ser humano que é, possui limitação em sua capacidade cognitiva, não sendo apto a prever todos os desdobramentos futuros. Por mais que se esforce, sempre encontrará limites em sua atividade intelectual.

\footnotetext{
${ }^{4}$ Segundo o dicionário Aurélio, discricionário é aquilo que não depende de condições; sem restrições.
} 
Em segundo lugar, a discricionariedade é necessária porque se a lei sempre vinculasse a conduta do administrador público, padronizaria a solução, tornando-a invariável mesmo perante situações que precisariam ser distinguidas e não poderiam ser catalogadas de antemão, justamente porque a "realidade do mundo empírico é polifacética e comporta inúmeras variantes. Donde, em muitos casos, uma predefinição normativa estanque levaria a que a providência por ela imposta conduzisse a resultados indesejáveis” (MELLO, 2014, p. 980).

Tentando detalhar ao máximo a legislação, na esperança de evitar a conduta criativa da autoridade pública, o legislador infraconstitucional corre o risco de ter o seu trabalho rotulado como injusto e/ou antidemocrático, pois nem sempre uma única solução prevista em lei de forma abstrata é a mais adequada para dialogar com uma realidade complexa, dentro de uma sociedade pluralista e de um território com dimensões continentais como o brasileiro.

Ademais, faz-se mister esclarecer que o correto é falar em apreciação discricionária e não em ato discricionário. Embora seja extremamente comum escutar que um determinado ato é discricionário, a expressão deve ser recebida apenas como uma forma alternativa de afirmar que o ato administrativo foi praticado no exercício da apreciação discricionária. Com efeito, discricionária é a competência do administrador público e não o ato administrativo. $\mathrm{O}$ ato corresponde tão somente ao produto do exercício desta competência. Então, a discrição não se encontra no ato, a despeito de ser nele, ou em sua omissão, que ela haverá de se revelar.

A discricionariedade não é atributo de ato algum. A doutrina, ao fazer referência à expressão "ato discricionário", trata sobre o ato administrativo que é produzido com base em uma competência estatal marcada por significativa margem de escolha, para o administrador, em relação ao ato em si ou a algum de seus elementos. É a falta desta precisão conceitual que leva a inúmeras e desnecessárias confusões. Duas merecem destaque. A primeira encontra-se presente na ideia de que existe uma antítese radical entre discrição e vinculação. Por sua vez, a segunda representa a ideia de que a discrição existiria em relação ao ato administrativo globalmente considerado, motivo pelo qual não existiriam tipos de discricionariedade.

É importante notar que em um mesmo ato pode haver o convívio entre vinculação e discricionariedade. Veja-se, a discrição é sempre relativa. No sentido abordado, é relativa porque, seja qual for o âmbito de liberdade conferido, ele só abarca os tópicos que a lei haja remetido à apreciação do agente público, e não os demais aspectos concernentes ao ato, pois sobre estes a norma não concedeu margem para qualquer interferência do administrador. 
A verdade é que, por serem inverídicas, as duas confusões supramencionadas precisam ser desfeitas. E, com base no que dispõe o jurista Thiago Marrara, isto é possível com apenas uma afirmação: “o poder de escolha que o ordenamento jurídico concede à autoridade pública pode recair sobre diferentes elementos do ato executado pela Administração Pública, com pequenas exceções nos tocantes aos motivos e às finalidades que o dirigem” (2012, p. 212).

Veja-se um exemplo de Bandeira de Mello (2014, p. 1003): se a norma dispuser que a “Administração Pública poderá conferir um prêmio de 1.000 reais ao funcionário que contar com 40 anos de serviço sem nenhuma falta e sem haver sofrido sanção disciplinar", no instante de concretização do Direito o agente público disporá de liberdade para expedir ou não o ato atributivo do prêmio (decidirá conceder ou não o prêmio), mas não poderá dispor quanto ao seu conteúdo (o valor) e motivo (o tempo de serviço e ausência de faltas e sanções).

Tendo em vista estas considerações, e ressalvados os elementos "motivo jurídico" e "finalidade primária", três são os campos de incidência do poder de escolha da Administração Pública, quais sejam: (i) a discricionariedade de agir, incidente sobre o elemento competência; (ii) a discricionariedade no agir, incidente sobre o elemento objeto; e (iii) a discricionariedade quanto à forma para agir, incidente sobre o elemento forma (MARRARA, 2012, p. 213).

2.1 Os Campos de Incidência da Discricionariedade Administrativa

$\mathrm{Na}$ discricionariedade de agir, que também pode ser nomeada de discricionariedade quanto à ação ou quanto ao exercício da competência administrativa, o poder de escolha reservado à autoridade pública diz respeito à sua atuação, ou seja, nestes casos, o administrador pode decidir se o Poder Público intervirá ou não perante a situação apresentada.

Em tese, o administrador público tem o dever de fiscalizar quando do recebimento de denúncia ou solicitação para apurar a ocorrência de infração de normas administrativas. Todavia, naquelas situações em que não é possível dimensionar um foco de ação específico cumpre à Administração Pública deliberar o que deve ser fiscalizado, sempre se pautando em sua capacidade fiscalizatória e, consequentemente, nos seus limites fáticos de atuação.

Em suma, em determinadas ocorrências o Poder Público pode ou não exercitar uma competência, surgindo, pois, um tipo de discricionariedade de ação. Esta discrição, contudo, não pode ser empregada como justificativa para omissões indevidas ou para a ineficiência dos órgãos e entidades que compõem a Administração Pública (MARRARA, 2012, p. 215).

Por sua vez, na discricionariedade de agir ou discricionariedade quanto ao conteúdo da ação administrativa, a Administração é obrigada a praticar um ato, mas detém margem de 
escolha quanto ao seu conteúdo. Ainda que a prática do ato seja obrigatória, e não uma mera faculdade, o legislador atribui ao agente público margem para escolha do conteúdo da ação.

Portanto, a discricionariedade administrativa no agir trata acerca da possibilidade de escolha da autoridade pública na elaboração do conteúdo do ato administrativo. Esta discrição pode ou não ser exercida em conjunto com a discricionariedade de agir. Isto significa que a discricionariedade de agir não deve ser confundida com a discricionariedade no agir, tendo em vista que cada uma delas designa margens de escolha diversas ao agente público atuante.

Para finalizar, na discricionariedade quanto às formalidades da ação, que também pode ser vista como discricionariedade quanto à forma para agir, a discrição incide sobre as formalidades de criação, instrumentalização ou divulgação do ato. Ela pode ser observada quando a legislação concede ao administrador margem de atuação para determinar a forma de produção do ato administrativo. E, novamente, vale lembrar que a discricionariedade de forma pode ou não vir acompanhada da discricionariedade de agir e da discricionariedade no agir.

A breve descrição dos tipos de discricionariedade pode ser utilizada para revelar que, a despeito do que foi mencionado previamente ao final do subtópico imediatamente anterior, existem sim tipos de discricionariedade administrativa e que, além de múltiplos, os mesmos são considerados independentes, podendo ou não aparecer de forma isolada ou cumulativa.

2.2 A Discricionariedade e os Conceitos Jurídicos Indeterminados

Cabe, ainda, desmistificar a afirmação de que discricionariedade e vinculação estão em sentidos opostos e, por isto, são noções necessariamente excludentes. Na tentativa de sanar mais esta confusão, será explorada a doutrina sobre os conceitos jurídicos indeterminados. Estes conceitos são aqueles que fazem referência ao mundo da razão prática, da sensibilidade, e, como consequência, são plurissignificativos. Ressentem-se de certa incerteza e fluidez.

Quando a legislação utiliza conceitos com conotação e denotação precisas, tem-se a vinculação. Mas quando o legislador se apodera de conceitos que padecem de certa fluidez e, portanto, caracterizam-se como plurissignificativos, concede a chamada discricionariedade. Assim, o fundamento da discrição reside no intento do Poder Legislativo de atribuir ao agente público o dever jurídico de buscar identificar e satisfazer, no caso prático, a finalidade da lei.

Partindo do pressuposto de que a discricionariedade constitui uma margem de escolha relativa a um ou mais elementos do ato administrativo, é correto deduzir que vinculação e discricionariedade não são características excludentes, mas que convivem em harmonia. 
Esta afirmação, nas palavras do professor Thiago Marrara (2012, p. 218):

(...) supera a ideia de que discricionariedade de que discricionariedade e vinculação são características do poder que somente poderiam existir de modo isolado em face de um mesmo ato da administração. Em outras palavras, contradiz o entendimento, muitas vezes repetido, de que um ato é ou vinculado ou discricionário.

Ocorre que a vontade do legislador, em maior ou menor grau, sempre estará presente no ato praticado pelo Poder Público, pois mesmo que haja liberdade de agir, no agir ou em relação às formalidades do ato, sempre haverá vinculação legal em relação aos motivos e finalidades públicas. $\mathrm{Na}$ totalidade de situações, em razão do princípio da juridicidade, serão sempre observados elementos vinculados, logo, não é possível imaginar um ato totalmente discricionário. Um mínimo de vinculação é condição para a existência do Estado de Direito.

Porém, também é impossível encontrar um ato que seja totalmente vinculado, tendo em vista que a discricionariedade corresponde a uma característica essencial do poder administrativo pelo fato de o legislador não ser capaz de prever todos os detalhes da atuação pública. É claro que só se transfere ao administrador a eleição, no caso concreto, da melhor solução para alcançar o interesse público porque seria materialmente inimaginável que o legislador pudesse prever todas as situações suscetíveis de ocorrerem, além de suas soluções.

Recomenda-se, apenas, que a margem de escolha discricionária não seja confundida com a atividade interpretativa do aplicador do Direito. Entende-se que a interpretação, que corresponde ao exame significativo do texto normativo, precede o momento de escolha das medidas autorizadas na norma legal. Logo, a interpretação do dispositivo legal a ser aplicado antecede e é condição imprescindível para que seja realizada a atividade discricionária.

Em realidade, a autoridade pública resta obrigada a interpretar o Direito antes de agir. E, em certas ocasiões, por ser uma atividade que demanda liberdade criativa, a interpretação pode dar margens a soluções diferenciadas. Ou seja, o mesmo texto legal, caso interpretado por pessoas distintas, pode gerar comandos normativos diversos e igualmente válidos. Esta é uma situação que ocorre quando o agente público se depara com conceitos fluidos.

Estes, na esteira do que tem sido afirmado, possuem uma concepção difícil de ser alcançada, pois apresentam um amplo campo de significação, necessitando da atividade interpretativa para que seja obtido o seu real sentido. São exemplos de conceitos jurídicos indeterminados: interesse público, notável saber, bons costumes e urgência. Os seus limites não são traçados com rigor pela lei, visto não comportarem uma determinação rigorosa. 
Karl Engisch, em sua obra "Introdução ao Pensamento Jurídico” (1996, p. 209), distingue os conceitos indeterminados em núcleo conceitual e halo conceitual. Sempre que o administrador possui uma noção clara do conteúdo e extensão do conceito, encontra-se no domínio do núcleo conceitual. Onde as dúvidas começam a surgir, inicia-se o halo conceitual.

No Brasil, esta é uma temática que ainda não possui entendimento uniforme, a despeito de ser constantemente debatida. Celso Antônio Bandeira de Mello (2008, p. 23), que tão bem discorreu sobre discricionariedade administrativa e controle jurisdicional, ensina que em decorrência da fluidez dos conceitos jurídicos indeterminados, a doutrina não deve "fechar os olhos" para a possibilidade de conviverem intelecções distintas, mas igualmente razoáveis, sobre a mesma norma, fato que permite ao administrador a escolha de qualquer uma delas.

Carlos Hermann Ule desenvolveu a "tese da sustentabilidade", também tratada por Antônio Francisco de Souza (1994, p. 50). Para estes estudiosos, existe um âmbito de pluridimensionalidade entre discricionariedade e vinculação, o que gera um terceiro espaço de relativa vinculação e liberdade. Este espaço seria decorrente da natureza de determinados conceitos jurídicos que comportariam uma série de decisões "sustentáveis", deixando o administrador livre para adotar qualquer uma das soluções que se encontram dentro do "quadro da sustentabilidade", pois, assim, estaria atuando em conformidade com a norma.

Em contrapartida, Eduardo García de Enterría (1995, p. 35-37) costumava aduzir que na aplicação dos conceitos indeterminados não há um processo volitivo, como ocorre na discricionariedade, mas um processo de aplicação e interpretação da lei. Para aquele, nos conceitos fluidos há somente uma solução justa na aplicação do caso concreto, enquanto que na discricionariedade sobrevive a possibilidade de pluralidade de soluções justas possíveis.

Para Von Laun, citado por Maria Sylvia Zanella Di Pietro (2003, p. 66), quando a legislação utiliza noções imprecisas, é função do intérprete encontrar a única solução possível, inexistindo discricionariedade, desde quando se trata de ação vinculada. As várias possibilidades aparentes previstas na norma não são equivalentes, porque, diante das particularidades do caso concreto, só uma será capaz de atingir o objetivo definido na lei.

Em que pese o debate doutrinário ilustrado, com posicionamentos certamente antagônicos, o importante é que o leitor não cometa o equívoco de acreditar que, graças à utilização de conceitos jurídicos indeterminados, o administrador público estaria totalmente livre para decidir e aplicar o dispositivo legal ao caso concreto a partir de um subjetivismo exacerbado, sem o estreitamento necessário das balizas presentes no ordenamento jurídico. 
Acreditar que os conceitos imprecisos concederiam à Administração Pública tamanho poder seria o mesmo que atribuir aqueles conceitos uma significação mágica. Neste sentido, resta válido salientar o escrito do já citado Celso Antônio Bandeira de Mello (2014, p. 996):

Tais palavras não têm condão de transformar as coisas, de reconstruir as realidades, de fabricar um universo de fantasia, como sucede nas histórias de fadas e contos infantis. Para o agente público não há 'abracadabras', justamente porque o Judiciário pode comparecer sob apelo dos interessados, a fim de confinar comportamento pretensamente discricionário ao plano da legitimidade e do respeito dos direitos e garantias individuais.

Em síntese: a margem de liberdade do sujeito na atividade de interpretação da legislação, bem como as diferentes interpretações que são geradas a partir de um único texto, por exemplo, em virtude dos conceitos jurídicos indeterminados, não significam que a norma extraída do texto garante certa margem de criatividade aos elementos do ato administrativos. A interpretação envolve uma margem de escolha quanto aos significados do texto normativo, não se extraindo desta margem, necessariamente, a discricionariedade administrativa.

A discricionariedade administrativa se reflete na margem de escolha do administrador público. Ocorre que esta discrição sempre convive com escolhas predefinidas pelo legislador, motivo pelo qual se sustenta que discricionariedade e vinculação variam casuisticamente. Entretanto, ainda importa compreender que, no contexto da constitucionalização do Direito Administrativo, no qual a sociedade atual está inserida, a discricionariedade administrativa não se vincula apenas às escolhas feitas pelo legislador infraconstitucional, ou seja, aquelas previstas no texto do dispositivo aplicável ao caso concreto, mas também resta vinculada ao conteúdo do sistema jurídico, pensado como um todo, e expresso através da Constituição.

\section{OS REFLEXOS DA CONSTITUCIONALIZAÇÃO DO DIREITO ADMINISTRATIVO NA DISCRICIONARIEDADE DA ADMINISTRAÇÃO}

A constitucionalização do Direito Administrativo se intensificou com a promulgação da Constituição de 1988 ao ter introduzido em seu texto valores e princípios que passaram a orientar a atuação dos três Poderes do Estado. O fenômeno da constitucionalização produziu reflexos imediatos no princípio da legalidade, que resultou consideravelmente ampliado, e na discricionariedade da Administração Pública, que por consequência lógica, resultou reduzida.

A discricionariedade administrativa foi conceituada como "a faculdade que a lei confere à Administração para apreciar o caso concreto, segundo critérios de oportunidade e conveniência, e escolher entre duas ou mais soluções, todas válidas perante o direito" 
(PIETRO, 2012, p. 90). Ocorre que, se o princípio da legalidade foi ampliado e o Direito concedeu supremacia formal e material ao texto constitucional, o resultado previsível destes acontecimentos é que a margem de liberdade da autoridade pública foi inevitavelmente reduzida, ao passo em que o controle jurisdicional dos atos administrados foi alargado.

A evolução do princípio da legalidade foi acompanhada pela evolução da discricionariedade estatal, como não poderia deixar de ser. Destarte, o crescimento do âmbito de incidência e/ou reconhecimento da legalidade foi seguida pela redução da discrição.

Conclui-se, portanto, que o fenômeno da constitucionalização do Direito reduziu a discricionariedade administrativa. Leia-se com cautela, pois a constitucionalização reduziu a discricionariedade, mas não a eliminou. E a explicação para tal não demanda grande esforço. Atualmente, os princípios e regras constitucionais são obrigatórios para a Administração Pública, cuja discrição fica limitada não só pela lei (legalidade em sentido estrito), mas por todos os valores e princípios consagrados na Constituição (legalidade em sentido amplo).

Assim, pode-se afirmar que houve uma ampliação do sentido da lei, na medida em que ela passou a ser vista (i) sob o aspecto formal, porque emana do Poder Legislativo; e (ii) sob o aspecto material, porque tem caráter axiológico e visa consagrar os valores constitucionais.

Logo, o ato administrativo, com selo da discricionariedade legítima, será aquele praticado com justa apreciação das consequências diretas e indiretas. Será legítimo se, e somente se, guardar vinculação com as regras legais e, concomitantemente, com o sistema jurídico como um todo. A discricionariedade passa a ser vista, então, como vinculada à Constituição e ao conjunto de direitos fundamentais (FREITAS, 2013, p. 417 e 431).

A autoridade pública, nos atos discricionários, goza de liberdade para emitir juízos decisórios, mas somente com o primordial escopo de promover o direito fundamental à boa administração. Já na prática de atos propriamente vinculados, o administrador emite o mínimo de juízo necessário à concretização de princípios e valores presentes no ordenamento jurídico.

A passagem do Estado Liberal para o Estado de Direito vinculou a lei aos ideários de justiça e prestigiou os direitos fundamentais do homem com a consagração do princípio da dignidade da pessoa humana. Isto posto, não restam dúvidas de que a Constituição vigente adotou a proeminência dos direitos fundamentais e, por outro lado, inaugurou uma nova leitura do princípio da legalidade, em sentido amplo, para abranger todos os valores e princípios consagrados, seja de forma explícita ou implícita, no texto constitucional de 1988. 
Como ressaltado, o princípio da legalidade, pela primeira vez, foi previsto de forma expressa na Carta Magna, sendo imposto à Administração Pública direta, indireta ou fundacional, de qualquer dos Poderes da União, dos Estados, Distrito Federal e Municípios. No entanto, isto não significa que a opção do constituinte foi pelo formalismo originário do positivismo jurídico, pois do próprio texto constitucional decorrem outros princípios que permitem afirmar o retorno do Estado de Direito, em substituição ao Estado Liberal.

Além da parte introdutória da Constituição Federal, onde se afirmam os seus princípios fundamentais, em várias outras passagens pode-se ver revelada a preocupação com determinados valores que devem ser observados no desempenho da função estatal, e que estão relacionados com a ideia de liberdade, segurança, desenvolvimento, igualdade, dentre outros.

E qual o motivo desta transição paradigmática? A doutrina majoritária enumera vários fatores que possam ter contribuído para a redução da discricionariedade, mas, dentre eles, destacam-se dois: (i) a teoria do desvio do poder; e (ii) a teoria dos motivos determinantes. Em linhas gerais, a primeira possibilitou ao Poder Judiciário o exame da finalidade perseguida pelo administrador com a prática do ato administrativo, para verificar se a mesma utilizou suas competências legais para atingir fins diversos daqueles previstos na legislação. Com isto, introduziu-se um primeiro aspecto de moralidade no âmbito do Direito Administrativo.

Por sua vez, a teoria dos motivos determinantes também limitou a discricionariedade do administrador público na medida em que autorizou o Judiciário a examinar a legalidade dos motivos que levaram a Administração Pública a praticar determinado ato. A consequência disto é que o magistrado pode, na atualidade, averiguar a adequação da decisão aos fatos apresentados pela aplicação dos princípios da proporcionalidade dos meios e dos fins.

Diante do exposto, resume-se que a discricionariedade administrativa não é mais vista como poder político, mas jurídico (porque limitada pela lei) e tem sofrido restrições por várias razões, dentre as quais merece relevo a constitucionalização do Direito administrativo, entendida como a inclusão dos princípios e valores constitucionais no conceito de legalidade.

\section{CONSIDERAÇÕES FINAIS}

A constitucionalização do Direito, quando compreendida em seus três sentidos: (i) de supremacia formal e material da Constituição; (ii) de incorporação de temas afetos aos ramos infraconstitucionais do Direito, aqui incluídas as matérias de Direito Administrativo; e (ii) de expansão das normas constitucionais, cujo conteúdo axiológico se propaga para todo o sistema jurídico, restringe de maneira significativa a atuação da Administração Pública. 
Adiante, ao analisar os seus desdobramentos sobre o poder discricionário das autoridades públicas, chegou-se à conclusão de que a margem de liberdade criativa do administrador, a ele sempre atribuída por dispositivo legal, foi consideravelmente reduzida, tendo em vista que a obrigatoriedade de atender às normas e princípios atualmente consagrados no texto constitucional brasileiro acabou por limitar a conduta da Administração.

O Estado de Direito coloca o Poder Executivo sob o império do ordenamento jurídico e, em decorrência, das regras e valores, escritos ou não, que o compõem. A discricionariedade só é válida se exercida em respeito a tais valores e regras. Logo, aqui resta demonstrado o princípio da juridicidade ou legalidade em sentido amplo (MARRARA, 2012, p. 212).

Portanto, o esforço central deste documento é comprovar que os valores e princípios previstos no ordenamento jurídico, principalmente aqueles dispersos no texto da Carta Magna, seja de forma expressa ou até mesmo implícita, tais como os da razoabilidade, proporcionalidade, interesse público, moralidade e justiça, limitam a atuação do ente estatal. Ou seja, na medida em que cresce o princípio da legalidade, reduz-se a discricionariedade.

Contudo, esta não desaparece, visto que a autoridade pública sempre gozará de alguma margem criativa para decidir, com base nas circunstâncias do caso concreto, qual a solução que melhor atende ao interesse público. E, conforme mencionado, isto ocorre porque o legislador, em razão de sua natureza humana, não consegue prever, de antemão, todos os eventos passíveis de ocorrer no futuro, bem como quais serão as soluções mais adequadas.

Por fim, em que pese não ser objetivo deste artigo estabelecer juízos de valor sobre as conclusões apresentadas, cabe deixar a seguinte reflexão: o processo de constitucionalização do Direito fez aumentar na sociedade brasileira a demanda por justiça, enquanto que a redução da discricionariedade ampliou o controle judicial dos atos administrativos, o que, por sua vez, trouxe maior segurança jurídica. E isto tem sido aclamado como um ponto positivo. Claro que, ao primeiro olhar, realmente o é. Ocorre que estes dois fatores, quando somados, possibilitaram o seguinte resultado, atualmente bastante criticado e discutido na doutrina: a expressiva judicialização de questões políticas e sociais. E agora, como conter os resultados? 


\section{REFERÊNCIAS}

ALEXANDRINO, Marcelo; PAULO, Vicente. Direito Administrativo Descomplicado. 19a ed. São Paulo: Método, 2011.

ALMEIDA, Fernando Dias Menezes de. Mecanismos de consenso no direito administrativo. In: ARAGÃO, Alexandre dos Santos; MARQUES NETO, Floriano de Azevedo (Coord.). Direito Administrativo e seus Novos Paradigmas. Belo Horizonte: Fórum, 2008.

ARAÚJO, Edmir Netto de. Curso de Direito Administrativo. São Paulo: Saraiva, 2005.

BARROSO, Luís Roberto. A Constitucionalização do Direito e suas Repercussões no Âmbito Administrativo. In: ARAGÃO, Alexandre Santos de; MARQUES NETO, Floriano de Azevedo (Coord.). Direito Administrativo e seus Novos Paradigmas. Belo Horizonte: Editora Fórum, 2012, p. 31-63, ISBN 978-85-7700-186-6.

ENGISCH, Karl. Introdução ao Pensamento Jurídico. Lisboa: Fundação Calouste Gulbenkian, 1996.

ENTERRÍA, Eduardo García de. La Lucha contra las Inmunidades del Poder. Madri: Civitas, 1995.

FAGUNDES, Miguel Seabra. Conceito de Mérito Administrativo. RDA - Revista de Direito Administrativo, Rio de Janeiro, n. 23, p. 1-16, jan./mar. 1951.

O Controle dos Atos Administrativos pelo Poder Judiciário. $3^{\text {a }}$ ed. Rio de Janeiro: Forense, 1975.

FREITAS, Juarez. Discricionariedade Administrativa: o controle de prioridades constitucionais. Revista NEJ - Eletrônica, v. 18, n.3, p. 416-434, set./dez. 2013.

HART, Herbert. O Conceito de Direito. Lisboa: Fundação Calouste Gulbenkian, 1994.

LIMA, Cirne. Princípios de Direito Administrativo. $7^{\text {a }}$ ed. São Paulo: Malheiros, 2007.

MARRARA, Thiago. A boa-fé do administrado e do administrador como fator limitativo da discricionariedade administrativa. RDA - Revista de Direito Administrativo, Rio de Janeiro, v. 259, p. $207-247$, jan./abr. 2012.

MAZZA, Alexandre. Manual de Direito Administrativo. 5a ed. São Paulo: Saraiva, 2015.

MEDAUAR, Odete. Direito Administrativo em Evolução. São Paulo: Revista dos Tribunais, 2003.

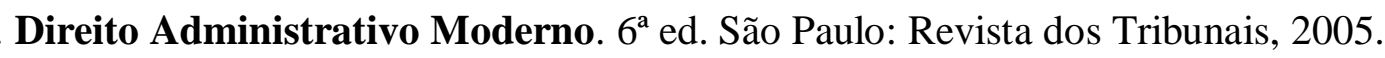


MEIRELLES, Hely Lopes. Direito Administrativo Brasileiro. $30^{\text {a }}$ ed. São Paulo: Revista dos Tribunais, 2005.

MELlo, Celso Antônio Bandeira de. Curso de Direito Administrativo. $31^{\mathrm{a}}$ ed. São Paulo: Malheiros, 2014.

Discricionariedade e Controle Jurisdicional. $2^{a}$ ed. São Paulo: Malheiros, 2008.

Grandes Temas de Direito Administrativo. São Paulo: Malheiros, 2009.

MOREIRA NETO, Diogo de Figueiredo. Curso de Direito Administrativo. 16 ${ }^{\text {a }}$ ed. Rio de Janeiro: Editora Forense, 2014.

PIETRO, Maria Sylvia Zanella di.; RIBEIRO, Carlos Vinícius Alves Ribeiro (Coord). Supremacia do Interesse Público: e outros temas relevantes do direito administrativo. Rio de Janeiro: Atlas, 2010.

PIETRO, Maria Sylvia Zanella di. Da Constitucionalização do Direito Administrativo: reflexos sobre o princípio da legalidade e discricionariedade administrativa. Atualidades Jurídicas - Revista do Conselho Federal da Ordem dos Advogados do Brasil, Belo Horizonte, ano 2, v. 2, p. 83-106, jan./jul. 2012.

Atlas, 2003.

Discricionariedade Administrativa na Constituição de 1988. $2^{a}$ ed. São Paulo:

QUEIRÓ, Afonso Rodrigues. Estudos de Direito Administrativo. Atlântida: Coimbra, 1968. SADDY, André. Elementos essenciais da definição de discricionariedade administrativa. Revista de Estudos Constitucionais, Hermenêutica e Teoria do Direito - RECHTD, v. 7, n. 2, p. 147-165, maio/agosto 2015.

SOUZA, Antônio Francisco de. Conceitos Indeterminados no Direito Administrativo. Coimbra: Almedina, 1994. 